\title{
Surface movement above an underground coal longwall mine after closure
}

\author{
André Vervoort \\ Department of Civil Engineering, KU Leuven, 3001 Leuven, Belgium \\ Correspondence to: André Vervoort (andre.vervoort@kuleuven.be)
}

Received: 18 April 2016 - Published in Nat. Hazards Earth Syst. Sci. Discuss.: 4 May 2016

Revised: 11 July 2016 - Accepted: 18 August 2016 - Published: 14 September 2016

\begin{abstract}
The surface movement in an area of about $22 \mathrm{~km}^{2}$ above the underground coal mine of Houthalen was analyzed based on Interferometry with Synthetic Aperture Radar (InSAR) measurements. After its closure in 1992, a residual subsidence was observed over a period of several years, followed by an uplift of the surface above and around the past longwall panels, whereby the rate of movement was, in absolute terms, of the same order for the two types of movements. The processes behind these movements are different. The process of subsidence is caused by the caving of the roof above the mined-out area and is mainly a mechanical stress-deformation process, including time-dependent aspects. However, the process of uplift is most probably caused by the swelling of the clay minerals in the argillaceous rocks in the coal strata after the flooding of the underground workings. Hence, the areas in which there is the greatest risk of damage to the surface infrastructure are not the same for the hazards linked to subsidence and uplift. For example, the zone in which the maximum uplift occurs clearly is at a different location from that of the zone with the maximum residual subsidence. There is no clear sign that the amount of mining underneath affects the residual subsidence, and there is no indication that the process of uplift is linked directly to the mining characteristics. It is more likely that uplift as the result of flooding is initiated at, or close to, the vertical shafts.
\end{abstract}

\section{Introduction}

Most research of the movements of the Earth's surface above underground mines has focused on the direct impact of mining, i.e., the impacts that occur during the lifetime of the mine. This is entirely logical because the largest amount of movement occurs during that period. Additionally, during that period, the mining company can limit the hazards, e.g., by selecting a different mining method (e.g., room and pillar instead of longwall), by backfilling the mined-out area instead of creating a goaf, or by changing the mining geometry. However, by introducing the concepts of sustainable mining, the long-term impact of mining on its surroundings has been receiving greater attention. This means that the period after the mine's closure is a period that should not be neglected. Surface movements after closure, which is the topic of this study, should be investigated in detail. In the past decades, not only have individual mines in western Europe been closed, but coal production has stopped in entire coal basins. As a consequence, the deep underground was flooded because access to the underground facilities was sealed off, and the underground pumping stations were dismantled. This created a new hazard, i.e., the uplift of the surface caused mainly by the swelling of clay minerals in the argillaceous rocks in the coal strata (Bekendam and Pöttgens, 1995). Although the order of magnitude of the movements in such uplifts is smaller than the subsidence that occurs during mining, cases have been reported in which uplifts have damaged buildings and the surface infrastructure (Baglikow, 2011; de Vent and Roest, 2013; Caro Cuenca et al., 2013). Therefore, studying this phenomenon is more than a pure scientific exercise. To date, other researchers have focused mainly on understanding the phenomenon (e.g., Herrero et al., 2012) and identifying general trends, whereby the link with the rise in water level was an important issue (Caro Cuenca et al., 2013; Devleeschouwer et al., 2008). In this study, we tried to provide better quantification of the movement after closure and the difference between the residual downward movement 


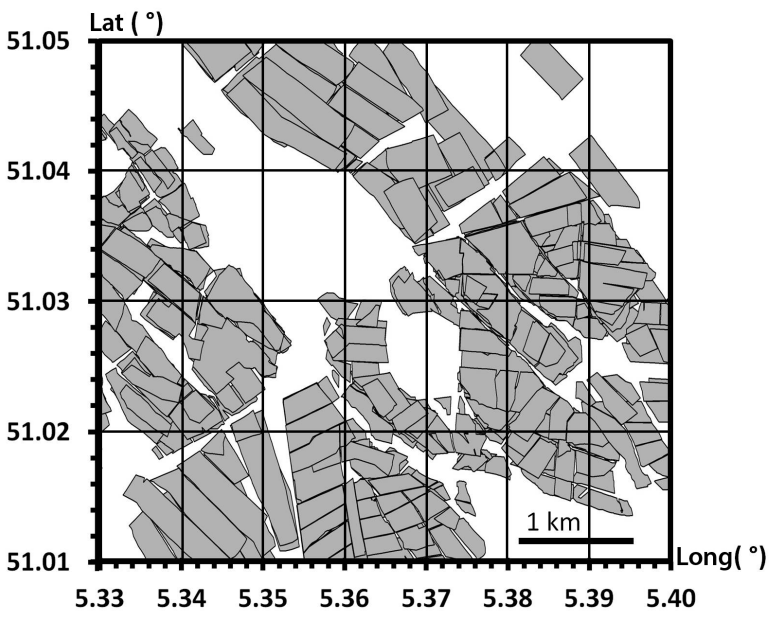

Figure 1. Map of longwall panels in area studied, i.e., between a latitude of $51.01-51.05^{\circ} \mathrm{N}$, and between a longitude of $5.33-5.40^{\circ} \mathrm{E}$.

and the ultimate uplift of the surface. To accomplish this, we studied the past mining directly underneath the observation points.

The underground coal mine of Houthalen, Belgium, was closed in 1992. For a period of nearly 2 decades (from 1992 through 2010), we analyzed the movements of the surface above the mine based on radar interferometry or Interferometry with Synthetic Aperture Radar (InSAR) measurements. The production of coal in this mine began in 1939, and, in 1964, the mine was merged (and connected underground) with the Zolder coal mine, which is situated to the west of the Houthalen mine. Production was stopped in both mines in 1992, and the access was sealed off. Hence, the underground pumps were also stopped, causing flooding of the underground work areas, the surrounding rock mass and caved zones.

Longwall mining with goaf was the method used in the mines, and different coal seams were mined. The area in which the detailed study of surface movement was conducted is situated from latitudes of $51.01-51.05^{\circ} \mathrm{N}$ and from longitudes of $5.33-5.40^{\circ} \mathrm{E}$, an area of approximately $5.0(\mathrm{EW})$ by 4.4 (NS) $\mathrm{km}^{2}$ (Fig. 1). At a certain $X-Y$ position within the mined area, one to eight different coals seams were mined. The combined mining height of the several seams varied from 2.0 to $12.3 \mathrm{~m}$ within this area. The height of the mining of individual panels varied from 0.9 to $2.7 \mathrm{~m}$, and, normally, about 10 to $40 \mathrm{~cm}$ of it were layers of waste rock. In some cases, either no waste rock was mined or only a few centimeters were mined, but, in other cases, almost $1 \mathrm{~m}$ of waste rock was recorded as having been mined. As the map indicates, certain zones were not mined. Apart from the zone around the vertical shafts (around the coordinates of latitude $51.025^{\circ} \mathrm{N}$ and longitude $5.370^{\circ} \mathrm{E}$ ), these unmined zones were mainly areas around faults. The latter were composed of a predominant set of NNW-SSE-striking normal faults with subordinate $\mathrm{N}-\mathrm{S}$ - to NE-SW-striking thrust faults. In the later decades of production, a typical longwall panel had dimensions of 200 by 800 to $1000 \mathrm{~m}$. The main and tail gates were immediately adjacent to the panel, and they were just single tunnels with a horseshoe cross section. Therefore, no barrier or remnant pillars existed between the longwall panels. In the area that we studied, the mining depth varied from 539 to $967 \mathrm{~m}$, and the mining occurred between 1932 and 1992. However, most of the panels were mined in the 1960s and 1970s. In Sect. 4, more details of the mining characteristics are provided, and their possible influences on the surface movements are discussed.

The coal strata in the Campine basin in northeast Belgium belong to the Upper Carboniferous strata (Westphalian unit), the time of the formation of many coal fields in Europe (Langenaeker, 2000; Vandenberghe et al., 2014). The top of the Upper Carboniferous strata generally occurs at depths of approximately $400-600 \mathrm{~m}$. The waste rock within these coal strata is composed mainly of argillaceous rocks, like shale and siltstone, and of sandstone and thin (unmined) coal layers. The sandstone is classed as medium-strong, with a typical uniaxial compressive strength (UCS) of $90 \mathrm{MPa}$ (Caers et al., 1997). However, values up to $160 \mathrm{MPa}$ have also been measured. The other types of rocks are classified as weak rock; e.g., siltstone was tested with a UCS value from 17 to $68 \mathrm{MPa}$ with an average of $46 \mathrm{MPa}$, and coal with a UCS value from 6 to $10 \mathrm{MPa}$ with an average of $7 \mathrm{MPa}$. The average values of Young's modulus for these three types of rocks were determined as $28 \mathrm{GPa}$ for sandstone, $9 \mathrm{GPa}$ for siltstone and $1 \mathrm{GPa}$ for coal (Caers et al., 1997). Overall, the successive strata are relatively thin (on the order of decimeters to meters in scale). The overburden is composed of weak to very weak geological material (e.g., sand, clay and chalk). Several aquifers and aquitards are present over the entire section of the overburden.

\section{Radar interferometry data}

Radar interferometry or Interferometry with Synthetic Aperture Radar (InSAR) is a recent remote sensing technique that allows the study of large time series of surface movements (Akcin et al., 2010; Herrera et al., 2009; Hongdong et al., 2011; Jung et al., 2007; Zhenguo et al., 2013). The movement of reflective surfaces (i.e., the so-called permanent scatterers) is followed during successive cycles of the satellite. There is high spatial coverage of the areas studied, at least if the area corresponds to a built environment. In comparison to conventional leveling methods, the advantages of radar interferometry include the following: (i) large areas can be covered for the same effort (e.g., a full concession area of a mine), (ii) measurements are conducted on a regular and frequent basis; i.e., one measurement per satellite revolution (35 days for the datasets used in this research) and (iii) a dense network of reflectors is available (sometimes every 10 to $20 \mathrm{~m}$ ). 
One of the disadvantages is that, when no reflective surfaces are identified in a specific zone, no information is available on the movement of the surface. For example, this was the case for the area studied in the zones composed of agricultural land, woodland and unused or semi-natural land. Other problems were (1) that the recorded movement corresponds to the reflection of a surface area of $4 \times 20 \mathrm{~m}$ and not of a discrete point and (2) that the recordings are not of the Earth's surface but of reflective objects, which can be hardened surfaces, such as the roofs of buildings (for the most part), as well as parking lots and roads. This means that for buildings, the type and depth of the foundation and the structure itself affect the movement of the reflector (Dang et al., 2014).

In this study, the European C-band ERS1/2 and ENVISATASAR satellite images were used, which were available for research through a European Space Agency (ESA) research proposal (Devleeschouwer et al., 2008). The recorded periods were for both sets from August 1992 through December 2000 (87 cycles of 35 days) and from December 2003 through October 2010 (72 cycles of 35 days), respectively. Generally, it is accepted that the linear velocities can be estimated with accuracies of about $1 \mathrm{~mm} \mathrm{yr}^{-1}$ (Marinkovic et al., 2009; Sousa et al., 2009). However, these values depend significantly on the number of images and the conditions in which they were obtained as regards to baselines, Doppler centroid distribution, selected pixel density, how they are connected and the presence of atmospheric effects. An accuracy of $1 \mathrm{~mm} \mathrm{yr}^{-1}$ was confirmed (Vervoort and Declercq, 2016) by comparing the InSAR data to the GPS reference points of the Belgian National Geographic Institute (NGI), linked to the reference stations of the Flemish Positioning Service (FLEPOS). For example the reference point HQ10 of NGI, situated $20 \mathrm{~cm}$ above the ground level within the same coal mine basin, was compared to the three closest reflectors surrounding this reference point and situated at a maximum horizontal distance of $35 \mathrm{~m}$. For a 5-year period of uplift, $31.0 \mathrm{~mm}$ was measured at the NGI reference point, while the InSAR reflectors showed a movement of respectively 25.5 , 29.1 and $29.9 \mathrm{~mm}$. As the location of the reference point and the three reflectors are different (plus different size between reference point vs. reflectors), it is normal that the four values are different, but the difference is small, showing that the InSAR data are precise for the purpose of this research.

\section{Analysis of surface movement}

Earlier research (Vervoort and Declercq, 2016) looked at annual increases in surface movement. It showed that, in this area at the end of the first period of observation (from August 1992 through December 2000), uplift had already been initiated in certain zones or for certain reflectors. In a similar way, it was observed that, at the start of the second period of observation (from December 2003 through October 2010), certain reflectors were still undergoing downward movement.
Therefore, in the first instance, we looked at 5-year time zones in each observation period, which can be considered to be characterized by a pure downward movement (for the first observation period from mid-August 1992 through midAugust 1997) or a pure upwards movement (for the second observation period from mid-September 2005 through midSeptember 2010). The remaining part of each observation period was also studied and for comparison purposes, a length of 2.5 years was chosen, i.e., the last 2.5 years of the first period and the first 2.5 years of the second period. These two 2.5-year time zones were from July 1998 through December 2000 and from December 2003 through June 2006, respectively. As the total first observation period was longer than 7.5 years and the second shorter, there was a gap between the time zones of 5 and 2.5 years in the first period and a small overlap in the second period, but the main advantage of doing so was that all time zones could be compared more easily. Hence, all scales for the graphs that correspond to the 2.5-year time zones are halved.

In this research, downward movement has a negative sign, and uplift has a positive sign; the same convention was used for the rate of movement (e.g., per year). However, when discussing the smallest (minimum) movement or the largest (maximum) movement, we considered the absolute value of the movement; in other words, when discussing the minimum rate, we did not apply the pure mathematical definition of minimum. For the area studied, no public data were available for the subsidence that occurred prior to the satellite observations.

\subsection{First observation period, characterized, on average, by subsidence}

In the 5 years from mid-August 1992 through mid-August 1997 , the area studied was characterized by an overall downward movement (Table 1, Fig. 2a). Only 2 out of 1073 reflectors were characterized by small upward movements, i.e., 3 and $6 \mathrm{~mm}$. In the overall picture, these can be neglected. It also justifies the choice of first considering the first 5 years instead of the entire observation period. Among the reflectors, $69 \%$ underwent residual subsidence ranging from -20 to $-40 \mathrm{~mm}$ over the 5 -year time zone (Fig. $2 \mathrm{a}$ ). The average subsidence was $-33 \mathrm{~mm}$, corresponding to an annual subsidence rate of about $-6 \mathrm{~mm}$. The maximum rate for the studied area was about $-16 \mathrm{~mm} \mathrm{yr}^{-1}$ (or a total of $-80 \mathrm{~mm}$ ). The distribution was slightly positive, i.e., a long tail for the larger subsidence movement. In addition, the spread (e.g., maximum minus minimum) was relatively large, i.e., $85 \mathrm{~mm}$. Earlier research showed that the variation was even larger if one considers the annual increases, i.e., the subsidence for each individual year, and not the total subsidence divided by 5 years (Vervoort and Declercq, 2016). For the time zone considered, the maximum increase per individual year was about $-33 \mathrm{~mm}$, i.e., 5 times the average rate over the 5 years 
Table 1. Information on total surface movement during the two times zones of 5 and 2.5 years considered in the first observation period for the total area studied.

\begin{tabular}{lcc}
\hline & $\begin{array}{c}\text { Period 1, 5-year time zone, } \\
\text { mid-August 1992 to mid-August } 1997\end{array}$ & $\begin{array}{c}\text { Period 1, 2.5-year time zone, } \\
\text { July 1998 to December 2000 }\end{array}$ \\
\hline Number of reflectors & 1073 & 1073 \\
Minimum & $5.8 \mathrm{~mm}$ & $14.9 \mathrm{~mm}$ \\
Average & $-32.9 \mathrm{~mm}$ & $-9.0 \mathrm{~mm}$ \\
Maximum & $-79.5 \mathrm{~mm}$ & $-40.5 \mathrm{~mm}$ \\
Standard deviation & $11.8 \mathrm{~mm}$ & $7.2 \mathrm{~mm}$ \\
Skewness* & 0.83 & 0.24 \\
\hline
\end{tabular}

* Positive skewness means a long tail for large values, i.e., large subsidence in the first observation period.

(a)
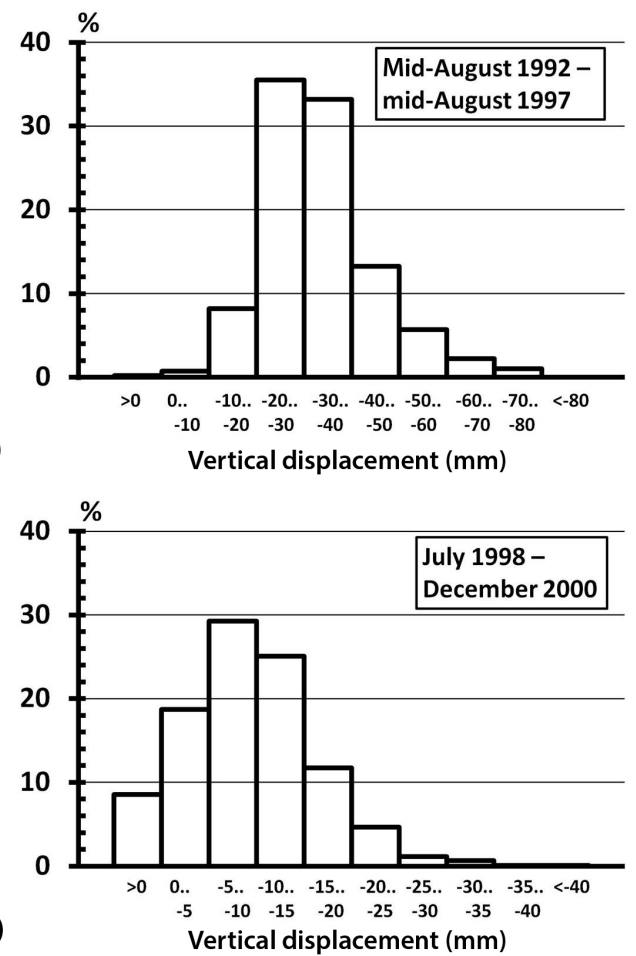

Figure 2. Distribution of total surface movement (in $\mathrm{mm}$ ): (a) period 1, 5-year time zone, from mid-August 1992 through midAugust 1997; (b) period 1, 2.5-year time zone, from July 1998 through December 2000. Largest subsidence (negative values) is plotted to the right.

$\left(-6 \mathrm{~mm} \mathrm{yr}^{-1}\right)$ and about twice the maximum average rate over the 5 years $\left(-16 \mathrm{~mm} \mathrm{yr}^{-1}\right)$.

If one looks at the spatial variation of the total surface movement over the 5-year time zone, it is apparent that the largest residual subsidence occurred in the northern central part of the area studied (Fig. 3a). Unfortunately, the reflectors were not evenly spread over the entire area. There were several zones with dimensions of a kilometer wide in which there were no reflectors at all. These zones, in this particular case, were farmland, woodland, unused land and a lake.
The combination of large zones without reflectors and the large fluctuation between neighboring points motivated us to present the individual reflectors instead of calculating a contour map. The latter would result in too much loss of detail and would result in large uncertainties for certain sub-zones.

Figure 3a shows that, although large movements may occur next to small movements, clustering is present. For example, in the western and southeastern parts of the area studied, the reflectors were mainly characterized by a residual subsidence of -20 to $-30 \mathrm{~mm}$ over the 5 years. Most reflectors with a total residual subsidence over the 5 years of $-60 \mathrm{~mm}$ or more correspond well with the mined-out area underneath (Fig. 1). In Sect. 4.2, a more detailed analysis is presented with the past exploitation. To better visualize the map of reflectors, the movement along a north-south line is presented in Fig. 4a. To have a sufficient number of reflectors along this line, a north-south zone was selected for a longitude between 5.37 and $5.38^{\circ} \mathrm{E}$, about $700 \mathrm{~m}$ wide in the east-west direction. A slightly longer transect was chosen, as shown in Figs. 1 and 3. No exploitation took place more to the north than latitude $51.05^{\circ} \mathrm{N}$ in the transect selected or its immediate surroundings; the same is true more to the south than latitude $51.005^{\circ} \mathrm{N}$ (Van Tongeren and Dreesen, 2004). In the northern and southern part, the residual movement was still subsidence but the values were small. In the zone between a latitude of 51.015 and $51.050^{\circ} \mathrm{N}$, mainly movements of $-20 \mathrm{~mm}$ and more were observed, with the largest values situated between 51.035 and $51.045^{\circ} \mathrm{N}$. The variation of the observed values was about $20 \mathrm{~mm}$. This can be explained by the inaccuracy of the method, by the variation in the eastwest direction, and by the local variation between neighboring points.

For the same (first) observation period, the last 2.5 years were also analyzed (Table 1, Fig. 2b). As mentioned earlier, all scales were halved to make the comparison easier, and the main reason for considering two time zones was that we already expected a significant number of reflectors with uplift at the end of the first observation period. About $8.5 \%$ of the reflectors underwent uplifts during this time zone of 2.5 years (Fig. 2b). Figure $3 b$ presents the locations of the 


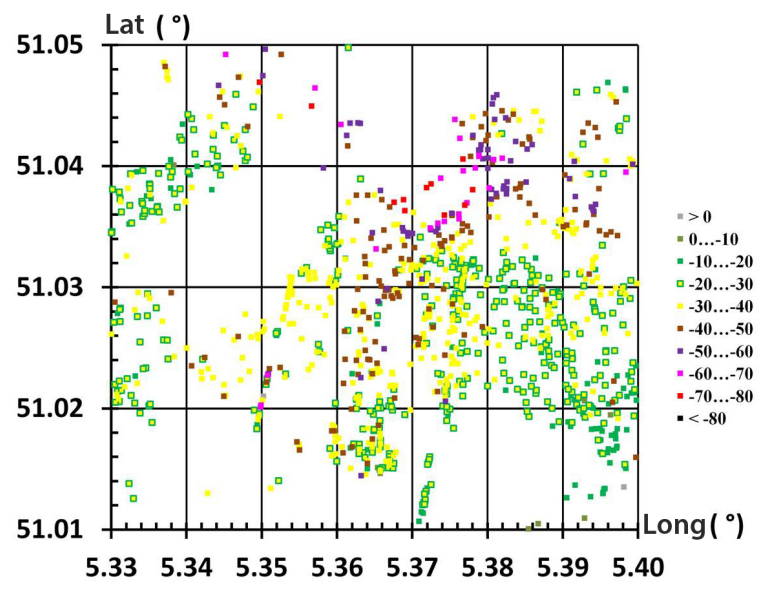

(a)

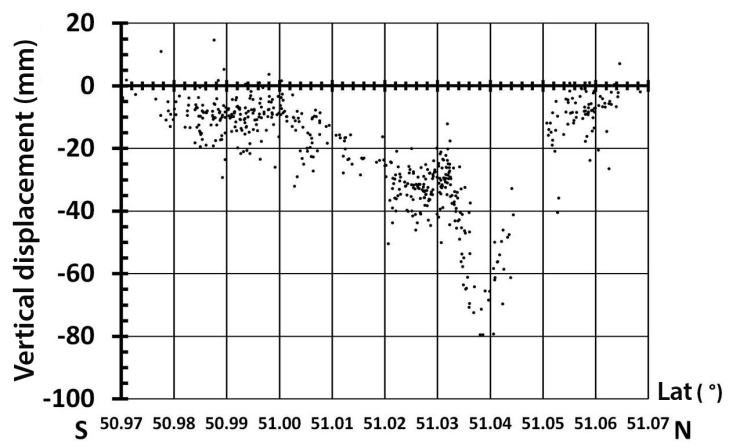

(a)

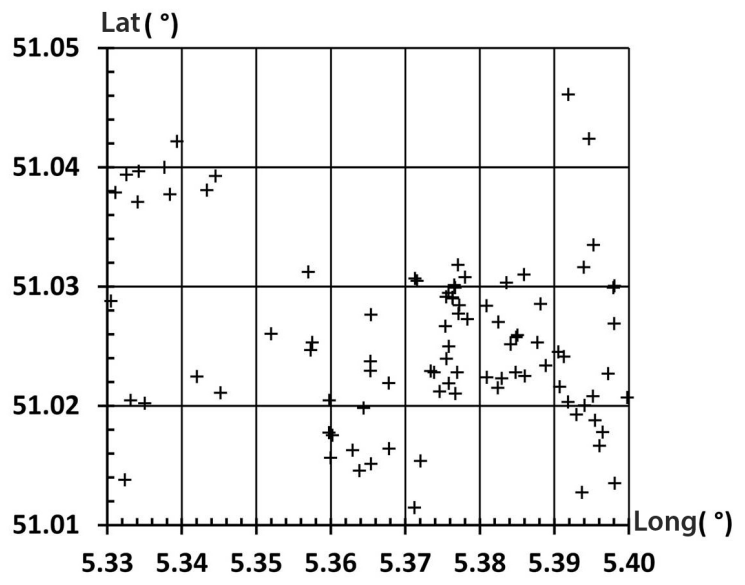

(b)

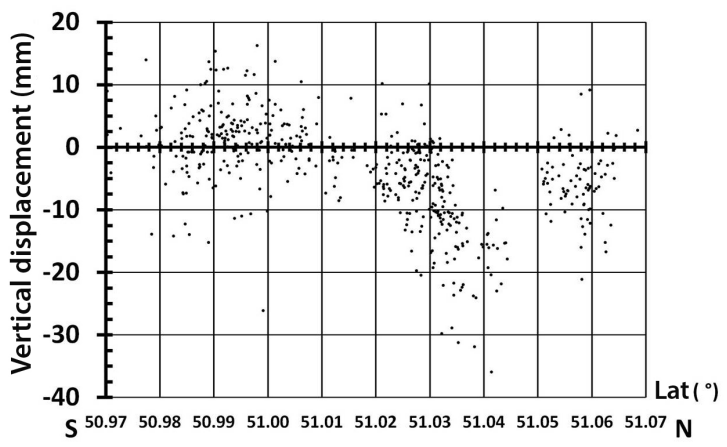

Figure 4. Variation of the total surface movement along a northsouth transect, situated for a longitude between 5.37 and $5.38^{\circ} \mathrm{E}$ : (a) period 1, 5-year time zone, from mid-August 1992 through midAugust 1997; (b) period 1, 2.5-year time zone, from July 1998 through December 2000.

(b)

Figure 3. Spatial variation of total surface movement in the area between a latitude of $51.01-51.05^{\circ} \mathrm{N}$, and a longitude of 5.33$5.40^{\circ} \mathrm{E}$ : (a) period 1, 5-year time zone, from mid-August 1992 through mid-August 1997 (all reflectors; color scale is in mm); (b) period 1, 2.5-year time zone, from July 1998 through December 2000 (only reflectors with a upward movement during this time zone).

corresponding reflectors. It is very clear that these locations are complementary to the zone of the largest residual subsidence observed in the first 5 years (Fig. 3a). The maximum subsidence rate observed was about the same as during the first 5 years, i.e., about $-16 \mathrm{~mm} \mathrm{yr}^{-1}$. The average rate was much smaller, i.e., $-3.6 \mathrm{~mm} \mathrm{yr}^{-1}$ instead of $-6.5 \mathrm{~mm} \mathrm{yr}^{-1}$.

When looking at the north-south transect (Fig. 4b), large subsidence values occurred in a similar area as in the 5year time zone. A peak was observed at a latitude of about $51.04^{\circ} \mathrm{N}$. The variation of the observed values remained about $20 \mathrm{~mm}$. As illustrated above, there was a nonnegligible number of reflectors characterized by uplifts, also above the unmined areas.

\subsection{Second observation period, characterized, on average, by an uplift}

In the 5-year time zone from mid-September 2005 through mid-September 2010 at the end of the second observation period, it becomes obvious that an uplift over the entire area took place (Fig. 5a). Only 6 of the 1808 reflectors had a slight downwards movement over this time period. This justifies the choice of first looking at the last 5 years of the second observation period. The smallest movement was $-10 \mathrm{~mm}(\mathrm{Ta}-$ ble 2). About $75 \%$ of the reflectors underwent uplifts that ranged from 30 to $60 \mathrm{~mm}$. The largest movement of all reflectors was $84 \mathrm{~mm}$, corresponding to an average rate of about $17 \mathrm{~mm} \mathrm{yr}^{-1}$, while the global average movement was $44 \mathrm{~mm}$ or nearly $9 \mathrm{~mm} \mathrm{yr}^{-1}$. This means that the rate of uplift was larger than the residual subsidence rate in the 5-year time zone following the closure of the coal mine (e.g., an average rate of -6 vs. $9 \mathrm{~mm} \mathrm{yr}^{-1}$ ). The shape of the distribution was negatively skewed, which means that only a few reflectors were observed with small values. As for the first 5 years in period 1, the variation in the increase of the uplift per individual year was larger than the average rate over the 5-year time zone. The maximum individual annual increase was $31 \mathrm{~mm}$.

There was a clear difference between the start and end of the second observation period, justifying the splitting of the 
Table 2. Information on total surface movement during the two times zones of 5 and 2.5 years considered in the second observation period for the total area studied.

\begin{tabular}{lcc}
\hline & $\begin{array}{c}\text { Period 2, 5-year time zone } \\
\text { mid-September 2005 to mid-September 2010 }\end{array}$ & $\begin{array}{c}\text { Period 2, 2.5-year time zone } \\
\text { December 2003 to June 2006 }\end{array}$ \\
\hline Number of reflectors & 1808 & 1808 \\
Minimum & $-9.9 \mathrm{~mm}$ & $-21.7 \mathrm{~mm}$ \\
Average & $43.9 \mathrm{~mm}$ & $11.8 \mathrm{~mm}$ \\
Maximum & $83.5 \mathrm{~mm}$ & $37.1 \mathrm{~mm}$ \\
Standard deviation & $13.8 \mathrm{~mm}$ & $7.6 \mathrm{~mm}$ \\
Skewness* & -0.58 & -0.19 \\
\hline
\end{tabular}

* Negative skewness means a long tail for small values, i.e., small uplift in the second observation period.

(a)
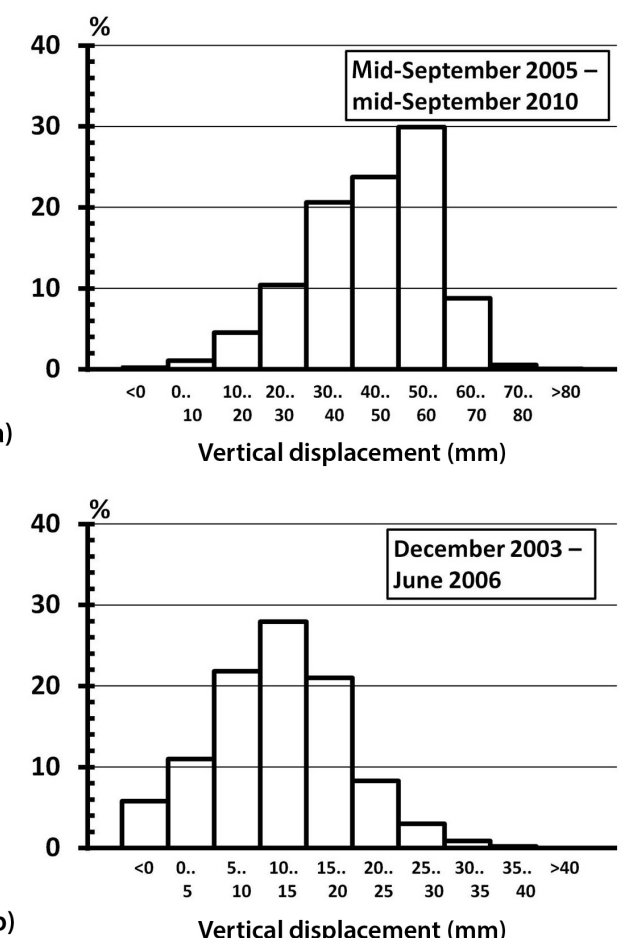

Figure 5. Distribution of total surface movement (in mm): (a) period 2, 5-year time zone, from mid-September 2005 through midSeptember 2010; (b) period 2, 2.5-years time zone, from December 2003 through June 2006. Largest uplift (positive values) is plotted to the right.

entire observation period in two. Figure $5 b$ shows the distribution of the increase in surface movement over the 2.5 years between December 2003 and June 2006. About $6 \%$ of the reflectors still had undergone subsidence (in comparison to $0.3 \%$ in the last 5 years). The classes between 5 and $20 \mathrm{~mm}$ of total increase (corresponding to an average annual rate between 2 and $8 \mathrm{~mm} \mathrm{yr}^{-1}$ ) contained about $71 \%$ of the reflectors for the first 2.5 years, while the classes for the same annual rate (i.e., from 10 to $40 \mathrm{~mm}$ total increase) contained only about one third at the end of the second observation period. (a)
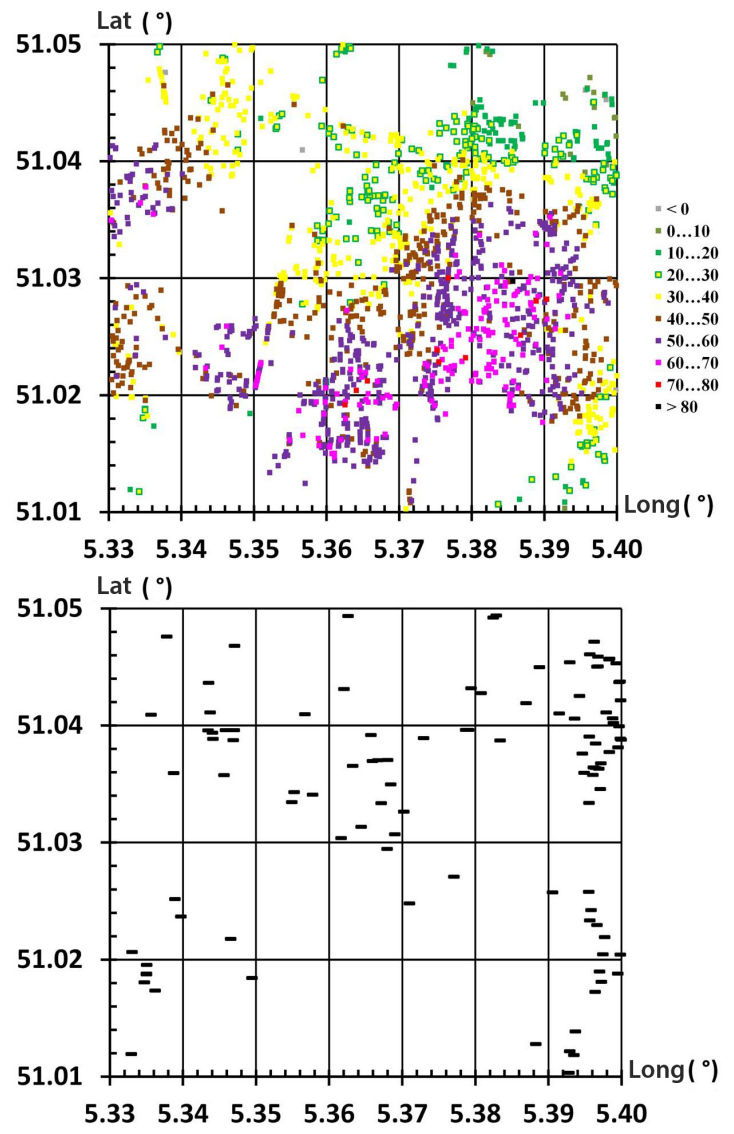

Figure 6. Spatial variation of total surface movement in the area between a latitude of 51.01 and $51.05^{\circ} \mathrm{N}$, and a longitude of 5.33 and $5.40^{\circ}$ E: (a) period 2, 5-year time zone, from mid-September 2005 through mid-September 2010 (all reflectors; color scale is in $\mathrm{mm}$ ); (b) period 2, 2.5-year time zone, from December 2003 through June 2006 (only reflectors with a downward movement during this time zone).

The map of the reflectors in the area studied now shows a completely different picture (Fig. 6a) in comparison to the first observation period. The largest uplift values were observed mainly in the central to southern part. In the north- 
ern part, where the largest residual subsidence was recorded, small uplift values were observed. In the 2.5-year time zone, from December 2003 through June 2006, numerous reflectors still had undergone subsidence in that northern part (Fig. 6b). In the eastern part (longitude larger than $5.39^{\circ} \mathrm{E}$ ) of the southern half, subsidence was still recorded, while this part was characterized by relatively small residual subsidence in the first observation period (compare Fig. 3a with Fig. 6b).

Figure 7 presents north-south transects that are similar to those for the first observation period. In the last 5 years of observation (Fig. 7a), the maximum uplift was observed at a latitude of about $51.024^{\circ} \mathrm{N}$. Less than $10 \mathrm{~mm}$ of uplift was recorded farther to the south than $50.994^{\circ} \mathrm{N}$ and farther to the north than $51.050^{\circ} \mathrm{N}$. These zones were not situated above exploitation panels; however, it is still worthwhile noting that there were uplifts in these areas. As for the subsidence, a variation of about $20 \mathrm{~mm}$ for a specific coordinate was observed again. Overall the curve is relatively symmetric. For the first 2.5 years of the second observation period (Fig. 7b), the values along this north-south transect confirm what was mentioned before; i.e., the most downward movement was situated in the northern and southern parts, while the peak in uplift became visible somewhere between 51.02 and $51.03^{\circ} \mathrm{N}$.

In comparison to these north-south transects, the eastwest transects showed a smaller variation, except, of course, that the movement evolved to zero away from the exploitation in the east. In comparison to the east of the area studied, where there was no exploitation, the exploitation of the Zolder mine bordered the exploitation of the Houthalen mine in the west. So, this clearly affected the movement. As an example, an east-west transect is presented in Fig. 8 for a latitude between 51.018 and $51.026^{\circ} \mathrm{N}$, which corresponds to the maximum uplift in the north-south transect. More to the east than a longitude of $5.41^{\circ} \mathrm{E}$, no reflectors were available as there is a nature reserve over a distance of about $3.5 \mathrm{~km}$ (without buildings or infrastructure). Although the variation is small between a longitude of 5.33 and $5.39^{\circ} \mathrm{E}$, the northsouth transect chosen earlier $\left(5.37-5.38^{\circ} \mathrm{E}\right)$ was at or close to the east-west maximum.

\section{Discussion of results}

\subsection{Location of maximum residual subsidence vs. location of maximum uplift}

As mentioned above, the movement is more complex than can be represented by a single value. Hence, one should be careful in replacing the individual measured values by an average or by a smoothed curve. However, for comparison purposes, such smoothed curves were drawn for the north-south transects, presented above. For the smooth curves of both of
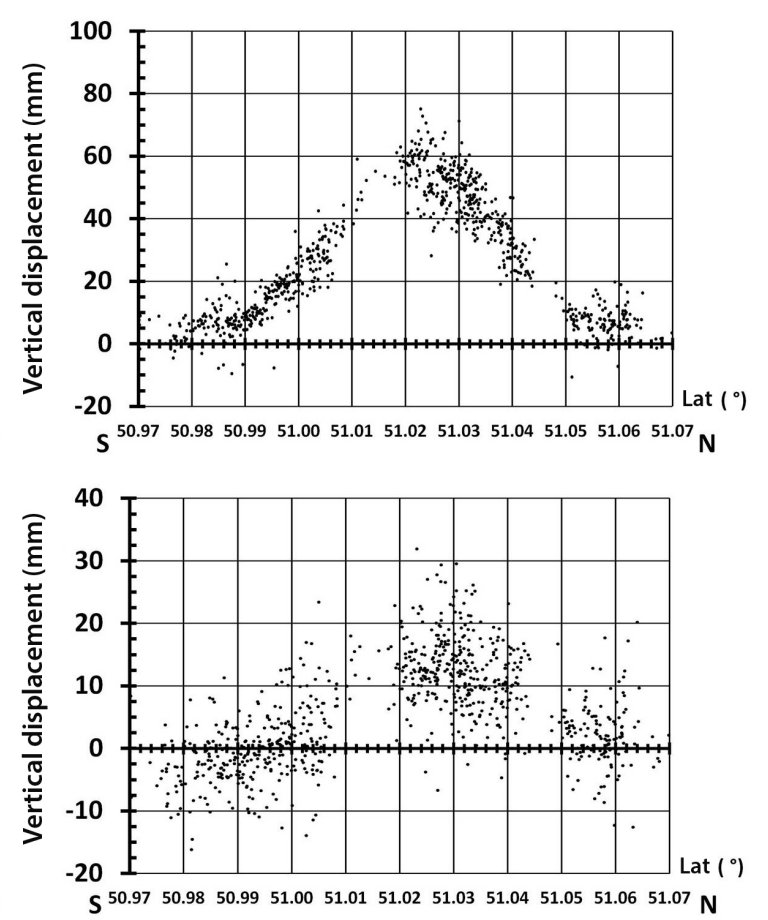

Figure 7. Variation of the total surface movement along a northsouth transect, situated for a longitude between 5.37 and $5.38^{\circ} \mathrm{E}$ : (a) period 2, 5-year time zone, from mid-September 2005 through mid-September 2010; (b) period 2, 2.5-year time zone, from December 2003 through June 2006.

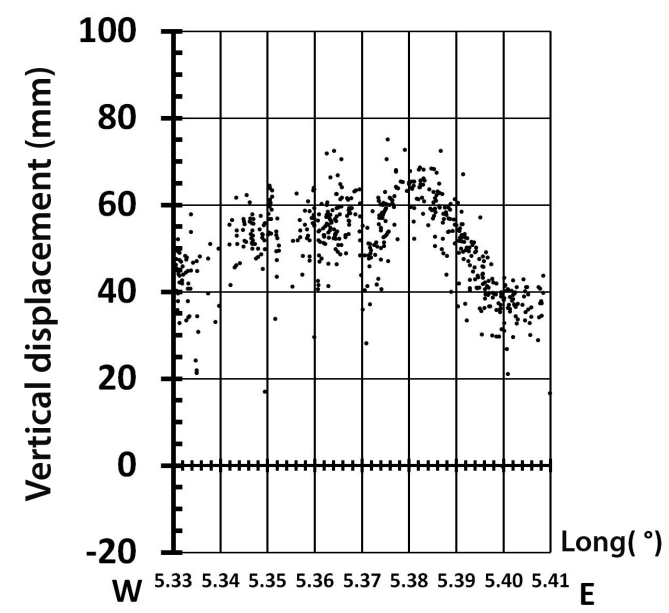

Figure 8. Variation of the total surface movement along a east-west transect, situated for a latitude between 51.018 and $51.026^{\circ} \mathrm{N}$ for the 5-year time zone in Period 2 (from mid-September 2005 through mid-September 2010).

the 5-year time zones that were studied, the following observations were made (Fig. 9a).

- The absolute movement over 5 years is the same order of magnitude as the residual subsidence and the uplift. 


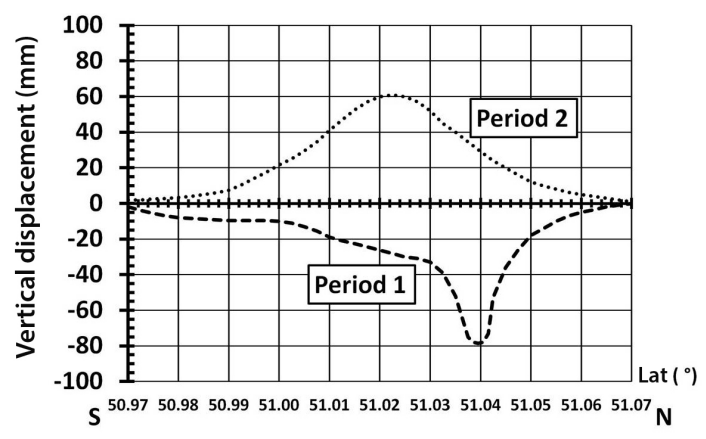

(a)

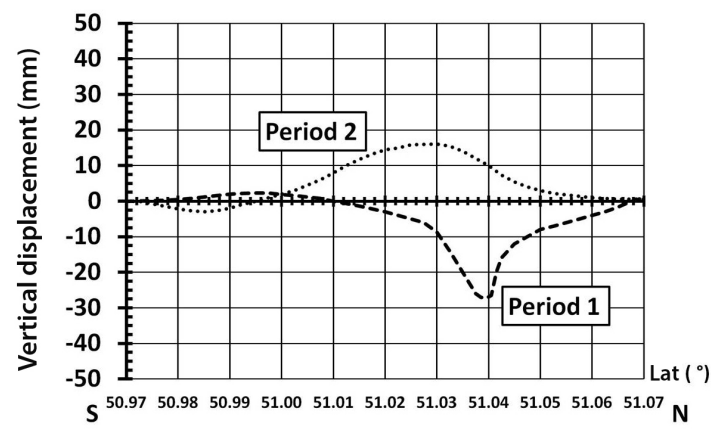

Figure 9. Smoothed curves fitted for the total surface movement along a north-south transect, situated for a longitude between 5.37 and $5.38^{\circ} \mathrm{E}$ : (a) the two 5-year time zones (see Figs. $4 \mathrm{a}$ and $7 \mathrm{a}$ respectively); (b) the two 2.5-year time zone (see Figs. $4 \mathrm{~b}$ and $7 \mathrm{~b}$ respectively).

- The maximum observed movements were at different locations. In the phase of residual subsidence, the maximum was situated around a latitude of $51.04^{\circ} \mathrm{N}$, while for the uplift phase, the maximum was observed around $51.020-51.025^{\circ} \mathrm{N}$. This is in agreement with the maps in Figs. $3 \mathrm{a}$ and $6 \mathrm{a}$.

- To the northern and southern end of the chosen transect, the movements evolved towards zero, away from the exploitation.

- The curve of the uplift is very symmetric, which is not the case for the curve of the residual subsidence. In Sect. 4.3, the mechanism behind the uplift is further discussed. All these points are also visible when looking at the smoothed curves for both 2.5-year time zones that were studied (Fig. 9b). The only difference is that, in the southern part (more to the south than a latitude of $51^{\circ} \mathrm{N}$ ), on average, there already was an uplift in the first observation period, while subsidence was observed, on average, in the second observation period.

When looking in detail at the movements at the locations of both maxima, the above can be more quantified (Table 3, Figs. 10, 11). Around both maxima, the 10 nearest reflectors were selected. The reflectors were not necessarily the same for the two observation periods, but they were the same within each of the two observation periods. The number of
Table 3. Information on the two locations, corresponding to the zones with approximately largest residual subsidence in the first period (Max $\operatorname{RES~SUBS}_{\text {) }}$ and largest uplift in the second observation period (Max UPLIFT $_{\text {) }}$ information on total movement of 10 reflectors around coordinates given in 5-year time zones studied and data on exploitation below these locations.

\begin{tabular}{llcc}
\hline Location & & Max $_{\text {RES SUBS }}$ & MaxUPLIFT \\
\hline \multirow{2}{*}{ Coordinates } & Lat & $51.036^{\circ} \mathrm{N}$ & $51.022^{\circ} \mathrm{N}$ \\
& Long & $5.375^{\circ} \mathrm{E}$ & $5.377^{\circ} \mathrm{E}$ \\
\hline \multirow{2}{*}{ Vertical movement over 5 years: } & & \\
& Min & $-37.4 \mathrm{~mm}$ & $-20.9 \mathrm{~mm}$ \\
\multirow{5}{*}{ First period } & Min & $-58.1 \mathrm{~mm}$ & $-31.2 \mathrm{~mm}$ \\
& Max & $-72.4 \mathrm{~mm}$ & $-40.0 \mathrm{~mm}$ \\
\cline { 2 - 4 } & Min & $33.0 \mathrm{~mm}$ & $50.2 \mathrm{~mm}$ \\
& Average & $39.3 \mathrm{~mm}$ & $59.7 \mathrm{~mm}$ \\
& Max & $46.3 \mathrm{~mm}$ & $68.0 \mathrm{~mm}$ \\
\hline \multirow{5}{*}{ Exploitation } & Number of longwalls & 4 & 6 \\
& Oldest year & 1968 & 1939 \\
& Most recent year & 1982 & 1959 \\
& Min depth & $686 \mathrm{~m}$ & $565 \mathrm{~m}$ \\
& Max depth & $796 \mathrm{~m}$ & $712 \mathrm{~m}$ \\
& Total mining height & $7.0 \mathrm{~m}$ & $9.3 \mathrm{~m}$ \\
\hline
\end{tabular}

10 reflectors is a compromise between zooming in on a particular area and having enough data to be statistically representative. Table 3 presents the minimum, maximum and average of the total vertical movement over the 5-year time zone. The variation of these values as a function of time is plotted in Figs. 10 and 11. As could be expected based on Fig. 9a, the difference between the two groups of curves is clear. For the first observation period, there was a small overlap between the two groups; i.e., the minimum of the residual subsidence of the location of the maximum residual subsidence was slightly smaller than the maximum of the other location studied, but the difference between the two averages was $27 \mathrm{~mm}$ over the 5 -year time zone. For the second observation period, there was no overlap between the two groups. The difference between their averages over the 5 years was $20 \mathrm{~mm}$.

Table 3 provides a summary of some basic information on the exploitation just underneath the two locations. The surface movement is of course not only affected by the mining directly below, but also by the mining around the locations. For an angle of draw of $45^{\circ}$ the extent of the zone of influence is even equal to the depth of mining. However, the impact decreases when moving away from a panel, which justifies considering the exploitation in the immediate vicinity. Figure 12 indicates both locations. Under the maximum of the residual subsidence, the mining was more recent than under the maximum of the uplift. Mining took place in the periods of 1968-1982 and 1939-1959, respectively. However, 1982 was still 10 years before closure (and the start of observation). A corner of a panel, which was mined in 1992 at a depth of $820 \mathrm{~m}$, is situated at about $250 \mathrm{~m}$ to the

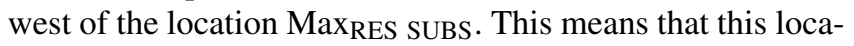


(a)

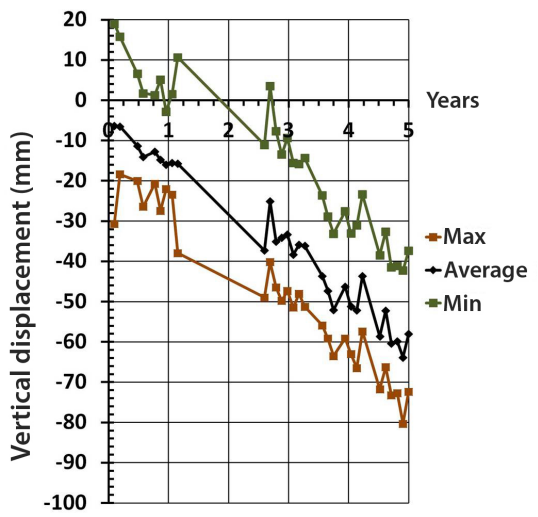

(b)

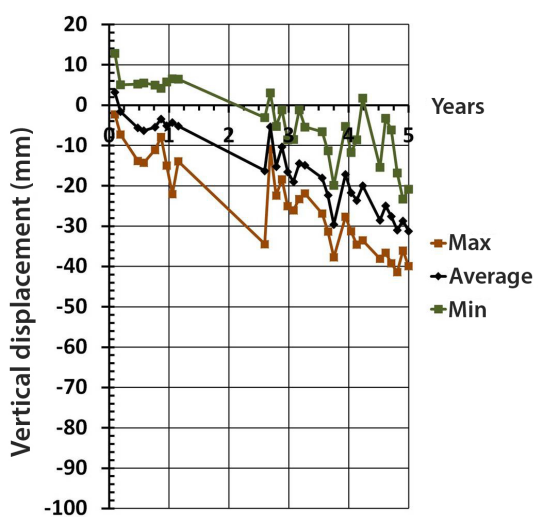

Figure 10. Evolution of subsidence over 5-year time zone in the first observation period (from mid-August 1992 through midAugust 1997): (a) 10 reflectors around coordinates $51.036^{\circ} \mathrm{N}$, $5.375^{\circ} \mathrm{E}$ (location Max RES SUBS); (b) 10 reflectors around coordinates $51.022^{\circ} \mathrm{N}, 5.377^{\circ} \mathrm{E}$ (location Max ${ }_{\text {UPLIFT). }}$ ).

tion is within the zone of influence of that panel. However, on the E-W transect (across the panel), we did not observe any maximum in residual subsidence above the most recent panel. When comparing the mining depth, mining height and the number of panels mined underneath the two locations, the mining characteristics were rather similar. Therefore, this means that, apart from possibly the time of mining, there was no clear indication concerning the causes of the difference between the movements of the two locations. In the next two paragraphs, more locations are compared, which will indicate whether the effect of the time of mining is significant.

\subsection{Influence of mining characteristics on residual subsidence after closure}

Mining by the longwall method results in caving above the mined-out areas, creating the goaf area. A roof height of 2 to 8 times the mined height generally is considered to be sufficient to fill up the mined height, plus the caved height (Peng, 1986). In the Campine basin, an average value of 5 times normally was assumed, corresponding to a bulking factor of 1.2. The caved zone is composed of blocks of broken mate- (a)

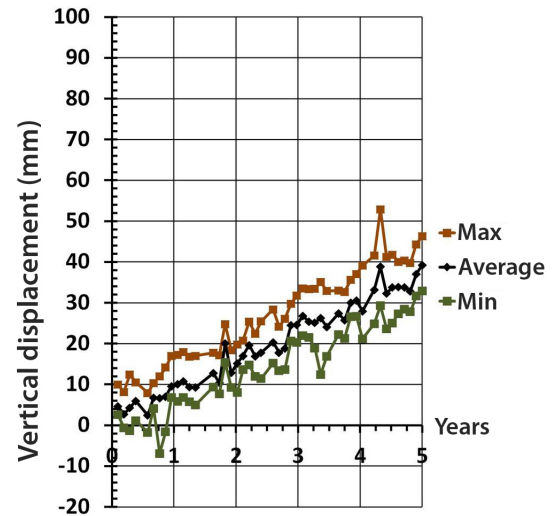

(b)

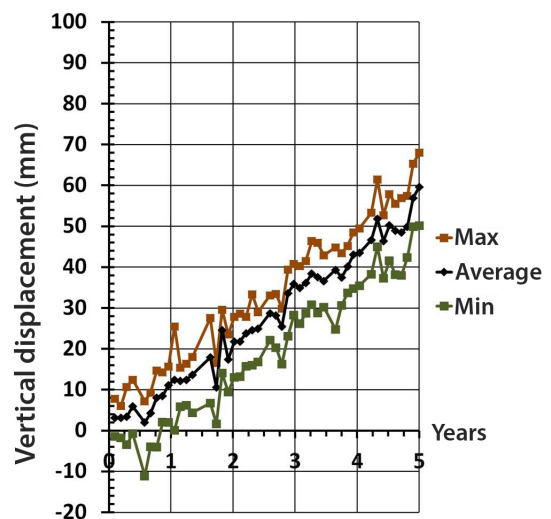

Figure 11. Evolution of uplift over 5-year time zone in the second observation period (from mid-September 2005 through midSeptember 2010): (a) 10 reflectors around coordinates $51.036^{\circ} \mathrm{N}$, $5.375^{\circ} \mathrm{E}$ (location Max RES SUBS), (b) 10 reflectors around coordinates $51.022^{\circ} \mathrm{N}, 5.377^{\circ} \mathrm{E}$ (location MaxUPLIFT).

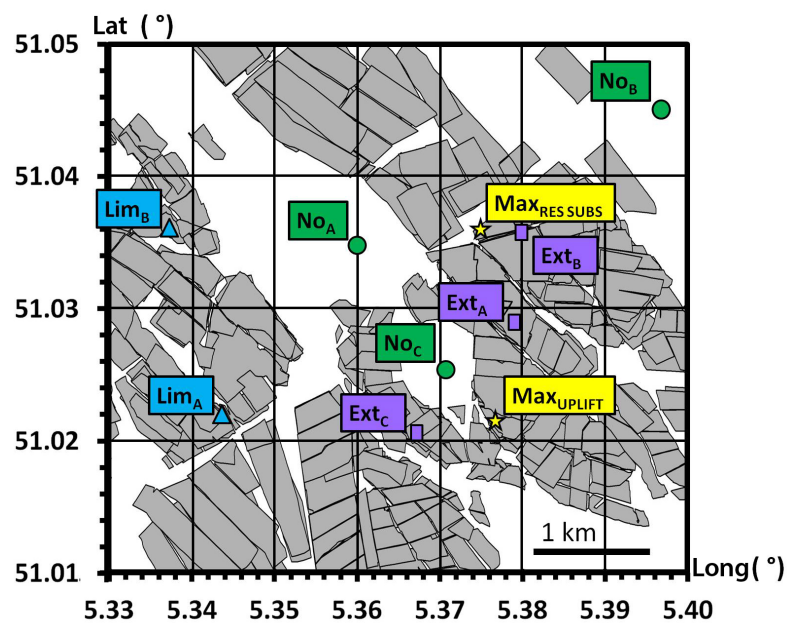

Figure 12. Indication of selected locations on map of exploitation panels in area studied (between a latitude of 51.01 and $51.05^{\circ} \mathrm{N}$, and between a longitude of 5.33 and $5.40^{\circ} \mathrm{E}$ ) to study link with mining characteristics. 
rial and includes a large number of small and large cavities. Hence, Young's modulus of this caved material is several orders of magnitude smaller than that of the original intact layers (Galvin, 2016). Over time, this volume is compressed progressively, but it will never reach its original state. Apart from the caving of the immediate roof layers, the rock further away fractures, and sliding along the induced fractures occurs. Still further away from the mining depth (i.e., closer to the surface), plastic and elastic deflections of layers also occur. All these phenomena result in the occurrence of subsidence at the surface. A typical trough shape is created, e.g., above and around a single panel that has been mined. The zone of influence at the surface is larger than the dimensions of the panel itself. By considering an angle of draw of $45^{\circ}$, as was often done for the Campine coal basin, the width of the zone of influence is about the depth of mining, which varied from 539 to $967 \mathrm{~m}$ in the area studied. By looking at the map of the exploitation (Fig. 12), this means that nearly the entire area studied is within the zone of influence of at least one longwall panel. For the coal basin that we studied, typical subsidence rates were 30 to $60 \mathrm{~mm} \mathrm{month}^{-1}$ in the months following the mining. Unfortunately, for the area studied, no public data were available for the subsidence that occurred prior to the satellite observations. Worldwide, the maximum subsidence ranges from 40 to $90 \%$ of the total mining height (Wagner and Schümann, 1991; Sheorey et al., 2000). In the Campine basin, values of 80 to $90 \%$ normally are used. This means that, for the area studied with a mining height varying from 2 to $12.3 \mathrm{~m}$, subsidence of 1.6 to $11.1 \mathrm{~m}$ could have occurred. There is no reason to assume that the general rules of the amount of residual subsidence following years or decades after mining would be any different from what can be considered as the globally accepted knowledge, e.g., more subsidence for larger mining heights and less subsidence for deeper longwalls (Galvin, 2016).

To study the possible link of the residual subsidence with the original mining characteristics in more detail, several groups of locations were selected (Fig. 12). First, three locations were selected where, underneath, no mining had ever taken place (Table 4a). Second, two locations with a small amount of mining, i.e., two panels only and with a total mining height of 2 and $2.5 \mathrm{~m}$, respectively (Table $4 \mathrm{~b}$ ). Third, three locations were selected with extensive mining, i.e., seven or eight panels and a total mining height of 9.2 to $10.3 \mathrm{~m}$ (Table 4c). As for the two locations with maximum movement (Table 3), the 10 reflectors in the most immediate vicinity were studied. It was not easy to find an adequate number of locations so proper analyses could be done; i.e., enough reflectors had to be present in both observation periods at a close distance, and the same mining conditions had to exist underneath these reflectors.

When one looks at the average total residual subsidence over the 5-year time zone, one gets $-29 /-26 /-37 \mathrm{~mm}$ (no mining), $-36 /-23 \mathrm{~mm}$ (limited mining), and $-29 /-46 /-33 \mathrm{~mm}$ (extensive mining), respectively.
Hence, one cannot conclude that the amount of mining underneath a relatively small area affects the residual subsidence, certainly if we also point out that location Ext $_{\mathrm{B}}$ $(-46 \mathrm{~mm})$ was situated very close to the location of the overall maximum of the residual subsidence in space. When looking at the minima or maxima, also no distinction is observed between the three groups of the amount of mining. This confirms what was observed when comparing both locations of maximum movement (Sect. 4.1).

By looking at the data of Table $4 \mathrm{~b}$ and $\mathrm{c}$ as a function of the mining depth, no clear trend is observed. For the two locations with a limited amount of mining, the most shallow mining resulted in the largest residual subsidence, while, for the three locations with extensive mining, the largest residual subsidence was for the deepest exploitation.

When comparing the two locations of maximum movement in Sect. 4.1, there was the possibility that more residual subsidence occurred directly above the more recent longwall panel. This would be logical. Therefore, Table 5 classifies the various locations as a function of the most recent longwall panel underneath. Taking into account the large number of possible parameters that influenced the results, the trend of these seven locations is indeed that the locations above the most recent panels resulted in larger residual subsidence. However, it must be pointed out that the location with the second-most recent mining has undergone, on average, less movement than one of the locations without mining underneath (i.e., $\mathrm{No}_{\mathrm{C}}$ with $-36.8 \mathrm{~mm}$ ). So, it certainly cannot be concluded that there is a simple one-on-one relationship with the time since exploitation. Two different panels were mined in 1990 and 1992, respectively, but, unfortunately, no reflectors or insufficient reflectors were present above these panels.

When comparing the residual subsidence in the northsouth transect (Fig. 9a) with the map of longwall panels, one can observe that the zone of influence is larger than expected based on the normally used values of the angle of draw. Based on the latter values and the depth of exploitation, the influence zone during the phase of subsidence should be limited to the zone between a latitude of 50.995 and $51.06^{\circ} \mathrm{N}$, since no exploitation took place any further north than a latitude of $51.05^{\circ} \mathrm{N}$ in the transect selected or its immediate surroundings or any further south than a latitude of $51.005^{\circ} \mathrm{N}$ (Van Tongeren and Dreesen, 2004). This was confirmed in the northern part of this transect. However, as far south as $50.98^{\circ} \mathrm{N}$, residual subsidence clearly was observed, i.e., $1.5 \mathrm{~km}$ further away than the theory would predict.

\subsection{Influence of mining characteristics on uplift after closure}

What was explained in the previous section is the process that was initiated by the caving process, and it can be seen as a mechanical stress-deformation process that includes timedependent aspects. However, once the underground activi- 
Table 4. Information of selected locations, i.e., movement of 10 reflectors around coordinates given over 5-year time zones in both observation periods and mining characteristics underneath locations: (a) no exploitation, (b) limited exploitation; (c) extensive exploitation.

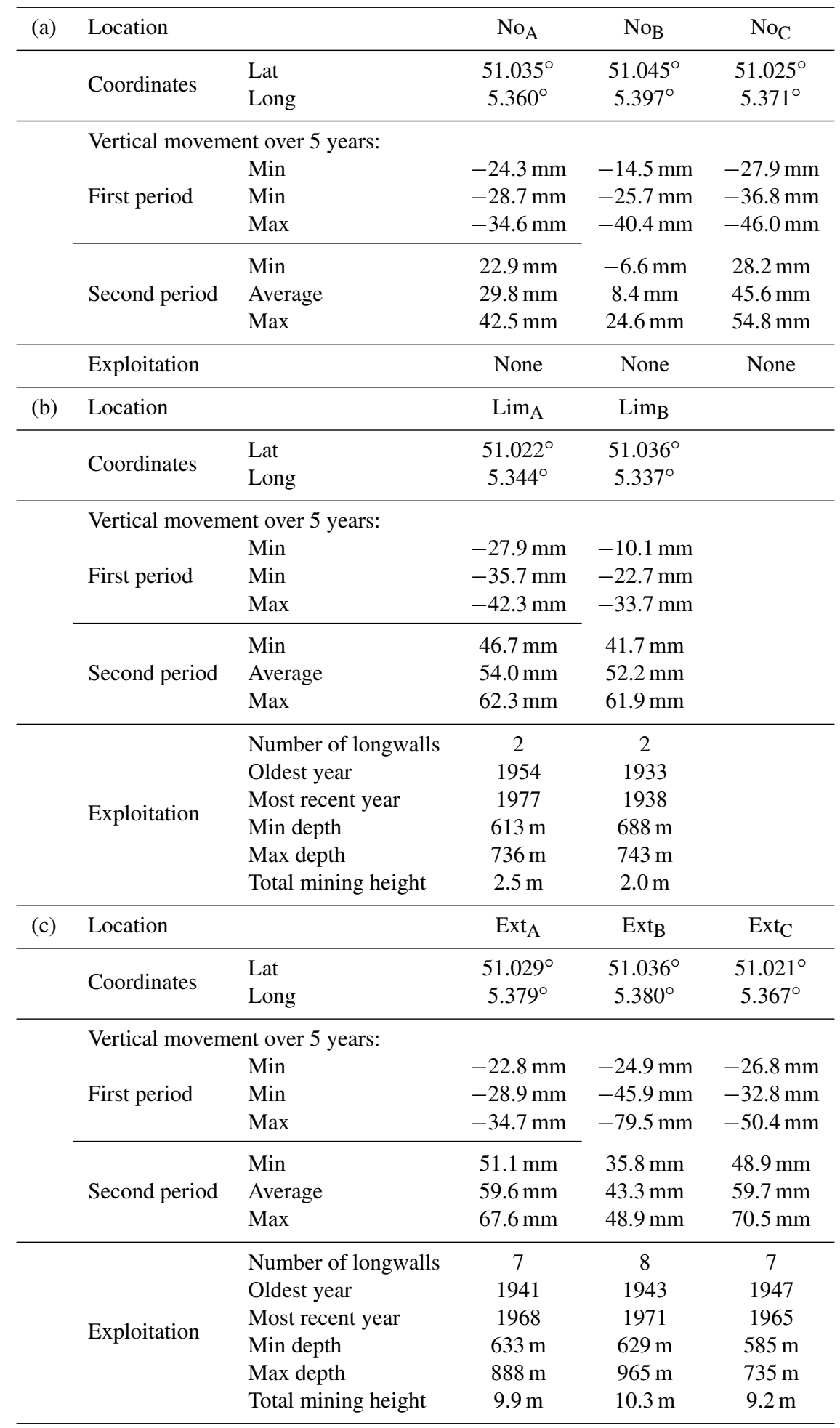


Table 5. Information on residual subsidence of the locations considered in Tables 3 and 4, reordered as a function of the most recent exploitation panel.

\begin{tabular}{lllll}
\hline $\begin{array}{l}\text { Most recent year } \\
\text { of exploitation }\end{array}$ & $\begin{array}{l}\text { Minimum residual } \\
\text { subsidence }\end{array}$ & $\begin{array}{l}\text { Average residual } \\
\text { subsidence }\end{array}$ & $\begin{array}{l}\text { Maximum residual } \\
\text { subsidence }\end{array}$ & Location \\
\hline 1938 & $-10.1 \mathrm{~mm}$ & $-22.7 \mathrm{~mm}$ & $-33.7 \mathrm{~mm}$ & Lim $_{\mathrm{B}}$ \\
1959 & $-20.9 \mathrm{~mm}$ & $-31.2 \mathrm{~mm}$ & $-40.0 \mathrm{~mm}$ & Max $_{\text {UPLIFT }}$ \\
1965 & $-26.8 \mathrm{~mm}$ & $-32.8 \mathrm{~mm}$ & $-50.4 \mathrm{~mm}$ & Ext $_{\mathrm{C}}$ \\
1968 & $-22.8 \mathrm{~mm}$ & $-28.9 \mathrm{~mm}$ & $-34.7 \mathrm{~mm}$ & Ext $_{\mathrm{A}}$ \\
1971 & $-24.9 \mathrm{~mm}$ & $-45.9 \mathrm{~mm}$ & $-79.5 \mathrm{~mm}$ & Ext $_{\mathrm{B}}$ \\
1977 & $-27.9 \mathrm{~mm}$ & $-35.7 \mathrm{~mm}$ & $-42.3 \mathrm{~mm}$ & Lim $_{\mathrm{A}}$ \\
1982 & $-37.4 \mathrm{~mm}$ & $-58.1 \mathrm{~mm}$ & $-72.4 \mathrm{~mm}$ & Max $_{\text {RES SUBS }}$ \\
\hline
\end{tabular}

ties ceased and the underground access was closed off, including dismantling of the pumping installations, the underground workings begins to be flooded (Bekendam and Pöttgens, 1995; Caro Cuenca et al., 2013; de Vent and Roest, 2013). In the beginning, the water finds its way through various pathways, including open roadways, permeable faults, and volumes of loose blocks. However, there is no reason the rock mass adjacent to the mined area or between mined areas would not be submerged, and this leads to new processes. In the literature (Herrero et al., 2012), the swelling of clay minerals of argillaceous rocks under the influence of water is considered to be the main factor for inducing uplift. Swelling is governed by the swelling pressure and is, therefore, linked to the mining depth. Caro Cuenca et al. (2013) showed the direct correlation between the increase of the water level in the underground areas and the uplift clearly. In all cases, the groundwater levels even showed a very high correlation $(\sim 0.97)$ with surface displacements. Apart from the uplift, Herrero et al. (2012) pointed out that, due to the flooding, the mechanical properties of argillaceous rocks are affected significantly by water, resulting in a decrease of 60 to $80 \%$ of their strength, which reactivates the downward settlement.

For the same average locations, as for the first observation period, the minimum, average and maximum uplift of the 5-year time zone for 10 reflectors are given in Table 4. By considering the three groups as a function of the amount of mining, one gets average uplifts of 30/8/46 mm (no mining), 54/52 mm (limited mining) and 60/43/60 mm (extensive mining), respectively. Hereby, it must be pointed out that the average value of $8 \mathrm{~mm}$ was recorded at the far NE of the study area, outside the mining area and at a distance of about $3 \mathrm{~km}$ from the location with the maximum uplift. Although the two smallest of these eight average values were for the group without mining and the two largest were for the group of extensive mining, one should be very careful in linking the amount of uplift with the amount of mining directly underneath. Earlier research also indicated that there is not a clear link between the uplift rate and mining (or the absence of mining) directly underneath (Vervoort and Declercq, 2016).
Often, one links the largest uplift to zones with the largest subsidence, and estimates the total uplift to be 3 to $4 \%$ of the total subsidence (Herrero et al., 2012). Bekendam and Pöttgens (1995) also concluded that, generally, the uplift is 2 to $4 \%$ of the subsidence; the latter conclusion is for the same Campine basin, but above the Dutch coal mines to the east. This cannot be confirmed by the area studied here and, of course, for the time periods considered; only the residual subsidence rate is known. As pointed out earlier, no public data were available for the subsidence that occurred prior to satellite monitoring, but by applying the rule of thumb for estimating the total subsidence, one could estimate that the subsidence was from about 1.5 to $11 \mathrm{~m}$ in the area studied, and $3 \%$ of this would mean that a total of 45 to $330 \mathrm{~mm}$ of uplift finally would occur above the mined-out area. If this were correct, then the uplift during the second observation period (until 2010) would have reached only the bottom part of this predicted range; in other words, one can still expect more uplift above the mining area and immediate surroundings.

As discussed in Sect. 4.2, the influence zone during the phase of subsidence should be limited to the zone between a latitude of 50.995 and $51.06^{\circ} \mathrm{N}$. In the northern part of the north-south transect that was considered, this was confirmed for the residual subsidence, but, in the south, the influence was about $1.5 \mathrm{~km}$ more to the south. For the uplift until 2010 (Fig. 9a), the zone of influence (e.g., an uplift of more than 5 to $10 \mathrm{~mm}$ ) corresponded well with the limits of 50.99 and $51.06^{\circ} \mathrm{N}$. However, after 2010 , the extent of the uplift zone could have increased.

Based on all of the information that was collected, there is no indication that the process of uplift is directly linked to the mining characteristics. It is more likely that the uplift as a result of the flooding is initiated at or close to the shafts, where most likely the deepest point is situated and where the pumping station was situated. From that central location, further flooding (in the horizontal direction) and rise of mine water (in the vertical direction) are extended, creating a further uplift at that central location and an initiation of uplift further away from the central area. 
Of course, the fact that mining and caving have taken place has an effect. It is the main reason that water flows into the underground workings. However, the local situation (e.g., the depth, extent or time of mining) does not seem to have a very significant influence on uplift. When looking at the interpolated curve of Fig. 9a, no local irregularities are noted; the curve itself also is very symmetric, much more so than the curve of residual subsidence (Fig. 9b).

\section{Conclusions}

Most research of surface movement above underground mines focuses on the direct effect of mining, i.e., within the lifetime of the mine, and less attention is given to the longterm impact of mining on surface movements. At the end of the last century, several coal basins were closed in Europe, and researchers began to observe a new phenomenon, i.e., the uplift of the surface as a consequence of the flooding of the underground workings (Bekendam and Pöttgens, 1995). In addition, cases were reported of damage to buildings and infrastructure during the uplift phase (Baglikow, 2011; de Vent and Roest, 2013; Caro Cuenca et al., 2013). During that period, satellite images with frequent and detailed measurements of the surface movement over large areas became available, so this topic could be studied further. To date, the focus has been mainly on understanding the phenomenon (e.g., Herrero et al., 2012) and identifying general trends, like for example the link with the rise in the water level (Caro Cuenca et al., 2013; Devleeschouwer et al., 2008). In this study, the residual subsidence after closure, as well as the initiation and further evolution of the uplift were investigated for an area of $22 \mathrm{~km}^{2}$ above the Houthalen coal mine, which was closed in 1992. We tried to better quantify the movement after closure and the difference between the residual downward movement and the ultimate uplift of the surface by considering past mining directly below the observation points. All this has led to the following conclusions.

- In the first 5 years following the closure of the coal mine (between mid-August 1992 and mid-August 1997), the area studied was still characterized by an overall downward movement; the average residual subsidence was $-33 \mathrm{~mm}$ over 5 years, corresponding to a rate of about $-6 \mathrm{~mm} \mathrm{yr}^{-1}$. The maximum rate for the studied area was about $-16 \mathrm{~mm} \mathrm{yr}^{-1}$ (or a total of $-80 \mathrm{~mm}$ ).

- Although large residual movements may occur next to small movements, clustering was present, and it resulted in areas with, on average, smaller residual subsidence and other areas with larger values; certainly when looking at the north-south transects, there was a clear zone in which the maximum residual subsidence occurred.

- In absolute terms, the rate of uplift was about the same order of magnitude as the residual subsidence, but, in fact, it was slightly larger; an average rate of uplift of $9 \mathrm{~mm} \mathrm{yr}^{-1}$ was observed for the period between midSeptember 2005 and mid-September 2010, in comparison to the average rate of $-6 \mathrm{~mm} \mathrm{yr}^{-1}$ in the 5 years following the closure.

- The zone in which the maximum uplift occurred was clearly at a different location from the zone with the maximum residual subsidence.

- The curve of the uplift along north-south lines was very symmetric, which was not the case for the curve of the residual subsidence.

- There was no clear sign that the amount of mining underneath a relatively small area had an effect on the residual subsidence. However, there was some indication that the locations above the most recent panels resulted in larger residual subsidence values. There is not a simple one-on-one relationship with the time since exploitation. The zone of influence was larger than one would expect based on the normally used values of the angle of draw and depth of mining.

- Based on all of the information that was collected, there was no indication that the process of uplift was directly linked to the mining characteristics. It is more likely that the uplift as a result of flooding was initiated at or close to the shafts; from that central location, the additional flooding (in the horizontal direction) and rise of mine water (in the vertical direction) were extended, creating additional uplift at that central location and initiating uplift further away from the central area.

Most concepts that one finds in textbooks dealing with surface subsidence above longwalls considers either the impact of mining a single panel or a relatively simple mining geometry and/or mining sequence (e.g., mining a single seam with adjacent panels, which are mined in a successive sequence). The latter is certainly typical for several countries, including the large coal producers, such as Australia, South Africa and the United States. In Europe, the situation was often different (Preusse et al., 2013). For the mine studied, a total of 10 seams were partly mined over a time period of 60 years (between 1932 and 1992) at depths varying from 539 to $967 \mathrm{~m}$. However, the situation was not significantly different when a shorter time is considered. For example, in the 1970s, seven seams still were being mined at depths varying from 556 to $824 \mathrm{~m}$. As one also observes on the map of longwall panels (Fig. 1), there was no systematic geometry or a systematic approach of mining the different panels. These observations probably explain why no clear link has been established between mining characteristics and residual subsidence. The entire area was rather in movement. For the amount of uplift, such one-on-one relationships were nonexistent. As illustrated above, one can best visualize the uplift as starting at or close to the shafts, whereby a further uplift occurred in 
the following years at that central location, and uplift was initiated farther away from this central area. This seems to be in accordance with the process of flooding the underground and the systematic rise of the water level. It will be interesting to investigate the further evolution of the uplift, when more recent satellite data become available.

The process of subsidence and the one of uplift are entirely different. The first is caused by a caving process and is mainly a mechanical stress-deformation process, including time-dependent aspects, while the process of uplift is caused by the swelling of the clay minerals in the argillaceous rocks in the coal strata, due to flooding. Hence, one cannot assume that the areas where one has the greatest risk for damage to infrastructure due to subsidence are the same areas for the hazards linked to the uplift process.

As for this area, no one-on-one relationships could be clearly identified between the surface movement and the mining characteristics, future research of this multivariate problem could benefit from using techniques including unsupervised learning and supervised learning (Noack et al., 2014). It would be best to have data on the initial subsidence, the residual subsidence and the uplift, combined with data on the mining characteristics.

\section{Data availability}

In this study, the European C-band ERS1/2 en ENVISATASAR satellite images were used, which were made available by ESA for research. To obtain these data, researchers who are interested have to submit a research proposal to ESA.

Competing interests. The author declares that he has no conflict of interest.

Acknowledgements. The input by Pierre-Yves Declercq from the Geological Survey of Belgium, Royal Belgian Institute of Natural Sciences, Brussels, is greatly acknowledged for providing the necessary basic data on surface movements and mining characteristics.

Edited by: T. Glade

Reviewed by: two anonymous referees

\section{References}

Akcin, H., Kutoglu, H. S., Kemaldere, H., Deguchi, T., and Koksal, E.: Monitoring subsidence effects in the urban area of Zonguldak Hardcoal Basin of Turkey by InSAR-GIS integration, Nat. Hazards Earth Syst. Sci., 10, 1807-1814, doi:10.5194/nhess-101807-2010, 2010.

Baglikow, V.: Schadensrelevante Auswirkungen des Grubenwasseranstiegs - Erkenntnisse aus dem Erkelenzer Steinkohlenrevier, Markscheidewesen, 118, 10-16, 2011.
Bekendam, R. F. and Pöttgens, J. J.: Ground movements over the coal mines of southern Limburg, The Netherlands, and their relation to rising mine waters, in: Land subsidence, Proceedings of the Fifth International Symposium on Land Subsidence, The Hague, IAHS, 234, 3-12, 1995.

Caers, J., Swennen, R., and Vervoort, A.: Petrography and X-ray computerized tomography applied as an integral part of a rock mechanical investigation of discontinuities, Transactions of the Institute of Mining and Metallurgy, Section B, Applied Earth Sciences, January-April 1997, 106, B38-B45, 1997.

Caro Cuenca, M., Hooper, A. J., and Hanssen, R. F.: Surface deformation induced by water influx in the abandoned coal mines in Limburg, The Netherlands observed by satellite radar interferometry, J. Appl. Geophys., 88, 1-11, 2013.

Dang, V. K., Doubre, C., Weber, C., Gourmelen, N., and Masson, F.: Recent land subsidence caused by the rapid urban development in the Hanoi region (Vietnam) using ALOS InSAR data, Nat. Hazards Earth Syst. Sci., 14, 657-674, doi:10.5194/nhess14-657-2014, 2014.

de Vent, I. and Roest, H.: Lagging mining damage in the Netherlands? Recent signs of soil movement in the Zuid-Limburg coal district, in: Proceedings of the XV International ISM Congress 2013, Aachen, Germany, 27-41, 2013.

Devleeschouwer, X., Declercq, P.-Y., Flamion, B., Brixko, J., Timmermans, A., and Vanneste, J.: Uplift revealed by radar interferometry around Liège (Belgium): a relation with rising mining groundwater, in: Proceedings of Post-Mining 2008, 6-8 February, Nancy, France, GISOS, Groupement d'intérêt scientifique de recherche sur l'Impact et la Sécurité des Ouvrages Souterrains, 13 pp., 2008.

Galvin, J. M.: Ground Engineering - Principles and Practices for Underground Coal Mining, Springer International Publishing AG, 684 pp., 2016.

Herrera, G., Fernández, J. A., Tomás, R., Cooksley, G., and Mulas, J.: Advanced interpretation of subsidence in Murcia (SE Spain) using A-DInSAR data - modelling and validation, Nat. Hazards Earth Syst. Sci., 9, 647-661, doi:10.5194/nhess-9-6472009, 2009.

Herrero, C., Muñoz, A., Catalina, J. C., Hadj-Hassen, F., Kuchenbecker, R., Spreckels, V., Juzwa, J., Bennett, S., Purvis, M., Bigby, D., and Moore, D.: Prediction and monitoring of subsidence hazards above coal mines (Presidence), RFCS Final report 2012, RFCR-CT-2007-00004, EUR 25057 EN, European Commission, Brussels, 131 pp., 2012.

Hongdong, F., Kazhong, D., Chengyu, J., Chuanguang, Z., and Jiqun, X.: Land subsidence monitoring by D-InSAR technique, Min. Sci. Technol., 21, 869-872, 2011.

Jung, H. C., Kim, S.-W., Jung, H.-S., Min, K. D., and Won, J.S.: Satellite observation of coal mining subsidence by persistent scatterer analysis, Eng. Geol., 92, 1-13, 2007.

Langenaeker, V.: The Campine basin. Stratigraphy, structural geology, coalification and hydrocarbon potential for the Devonian to Jurassic, Aardkundige Mededelingen, 10, 142 pp., 2000.

Marinkovic, P., Ketelaar, G., van Leijen, F., and Hanssen, R. F.: INSAR Quality Control: Analysis of five years of corner reflector time series, in: Proceedings of "Fringe 2009 Workshop", edited by: Osten, W. and Kujawinska, M., Frascati, Italy, 8 pp., 2009.

Noack, S., Knobloch, A., Etzold, S. H., Barth, A., and Kallmeier, E.: Spatial predictive mapping using artificial neural networks, 
in: Proceedings of the International Archives of the Photogrammetry, Remote Sensing and Spatial Information Sciences, Volume XL-2, 2014 ISPRS Technical Commission II Symposium, Toronto, Canada, 79-86, 2014.

Peng, S. S.: Coal mine, Ground Control, 2nd Edn., John Wiley \& Sons, 491 pp., 1986.

Preusse, A., Kateloe, H. J., and Sroka, A.: Subsidence and uplift prediction in German and Polish hard coal mining, Das Markscheidewesen, 120, 23-34, 2013.

Sheorey, P. R., Loui, J. P., Singh, K. B., and Singh, S. K.: Ground subsidence observations and a modified influence function method for complete subsidence prediction, Int. J. Rock Mech. Min., 37, 801-818, 2000.

Sousa, J. J., Hooper, A. J., Hanssen, R. F., and Bastos, L. C.: Comparative study of two different PS-INSAR approaches: DEPSI vs. STAMPS, in: Proceedings of "Fringe 2009 Workshop", edited by: Osten, W. and Kujawinska, M., Frascati, Italy, 8 pp., 2009.
Vandenberghe, N., De Craen, M., and Beerten, K.: Geological framework of the Campine Basin: Geological setting, tectonics, sedimentary sequences. External report SCK · CEN-ER-262 14/MDC/P-43, 2014.

Van Tongeren, P. and Dreesen, R.: Residual space volumes in abandoned coal mines of the Belgian Campine basin and possibilities for use, Geol. Belg., 7, 157-164, 2004.

Vervoort, A. and Declercq, P.-Y.: Surface movement above old coal longwalls after mine closure, accepted for publication, International Journal of Mining Science and Technology, in preparation, 2016.

Wagner, H. and Schümann, E. H. R.: Surface effects of total coalseam extraction by underground mining methods, J. SAIMM, 91, 221-231, 1991.

Zhenguo, L., Zhengfu, B., Fuxiang, L., and Baoquan, D.: Monitoring on subsidence due to repeated excavation with DInSAR technology, International Journal of Mining Science and Technology, 23, 173-178, 2013. 